Linke/Hau

Internationales Zivilverfahrensrecht 



\section{Internationales Zivilverfahrensrecht}

\section{Grundriss}

Begründet von

Prof. Dr. Hartmut Linke $†$ Richter am Oberlandesgericht und Honorarprofessor an der Ruhr-Universität Bochum

fortgeführt von

Prof. Dr. Wolfgang Hau o. Professor

an der Universität Passau

5. völlig überarbeitete Auflage

2011

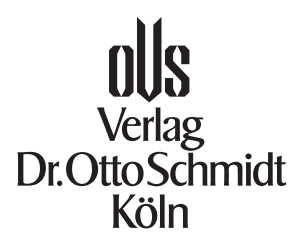


